\title{
Seasonal variation in the copepod community structure from a tropical Amazon estuary, Northern Brazil
}

\author{
ANDRÉ MAGALHÃes ${ }^{1}$, NATÁlia da R. LEITE ${ }^{1}$, JOÃo G.S. SILVA ${ }^{1}$, LUCI C.C. PEREIRA ${ }^{2}$ \\ and RAUQUÍRIO M. DA COSTA ${ }^{1}$ \\ ${ }^{1}$ Laboratório de Plâncton e Cultivo de Microalgas, Universidade Federal do Pará, Instituto de Estudos Costeiros, \\ Alameda Leandro Ribeiro s/n, Aldeia, 68600-000 Bragança, PA, Brasil \\ ${ }^{2}$ Laboratório de Oceanografia Costeira e Estuarina, Universidade Federal do Pará, Instituto de Estudos Costeiros, \\ Alameda Leandro Ribeiro s/n, Aldeia, 68600-000 Bragança, PA, Brasil \\ Manuscript received on August 1, 2008; accepted for publication on October 7, 2008; \\ presented by ALEXANDER W.A. KELLNER
}

\begin{abstract}
The main purpose of this study was to investigate the seasonal variation of copepod community structure during the months of July, September and November 2003 (dry season) and January, March and May 2004 (rainy season) in the Curuçá estuary, northern Brazil. Samples were collected during neap tides via gentle $200 \mu \mathrm{m}$ mesh net tows from a small powerboat. Measurements of surface water conductivity were accomplished in situ using an electronic conductivimeter and salinity was later obtained through the transformation of the conductivity values. Salinity varied seasonally from $7.2 \pm 0.1$ to $39.2 \pm 1.8$ (mean \pm standard deviation) and was influenced mainly by differences in the amount of rainfall between the studied sampling seasons. In total, 30 Copepoda taxa were identified and Acartia tonsa comprised the most representative species throughout the entire studied period followed by Acartia lilljeborgii, Subeucalanus pileatus and Paracalanus quasimodo. In the present study, the density values, ecological indexes and copepod species dominance presented a clear seasonal pattern, showing that the studied area may be considered seasonally heterogeneous in relation to the investigated parameters.
\end{abstract}

Key words: copepod, salinity, ecological indexes, seasonal changes, Brazil.

\section{INTRODUCTION}

Mangrove estuaries are located in tropical and subtropical regions and in these ecosystems phytoplankton and zooplankton productivity are sustained by the input of organic and inorganic nutrients originated from adjacent mangrove forests (Yáñez Arancibia et al. 1993, Schwamborn et al. 1999). In these environments copepods are usually the dominant zooplanktonic component comprising 60 to $80 \%$ of the total biomass (López-Ibarra and Palomares-García 2006) and playing an important role as prey for many juvenile and adult zooplanktophage fish (Schipp et al. 1999, Sommer et al. 2002) becoming a

Correspondence to: André Magalhães

E-mail: perezmagalhaes@hotmail.com key factor in the control of fish stock sizes (Payne and Rippingale 2001, Evjemo et al. 2003). As part of the pelagic food webs, copepods also contribute transferring energy and organic matter from the primary producers to the higher trophic levels of the aquatic system (Parsons et al. 1984). More recently, studies have also highlighted the role of copepods in the consumption of carbon produced by the microbial loop (Champalbert and Pagano 2002, Sommer and Stibor 2002).

The seasonal and spatial variability observed in the occurrence and distribution of copepods are directly related to abiotic (e.g. salinity, turbidity and temperature) and biotic parameters (e.g. competition, predation, food habits and food availability) or to a combination of both 
(Escribano and Hidalgo 2000, Beyst et al. 2001). The relationship between distribution of copepods and environmental variables have been studied in several estuaries (e.g. Hassel 1986, Soetaert and Rijswijk van 1993, Sarkar and Choudhury 1998, Lawrence et al. 2004, David et al. 2007) and salinity has been shown to be (Ara 2004, Froneman 2004, Uriarte and Villate 2005, Li et al. 2006) one of the main factors controlling species development and seasonal distribution of copepods in estuarine and marine environments because the organism's capacity to osmoregulate affects ecological tolerances (Rippingale and Hodgkin 1977, Cervetto et al. 1999).

According to Islam et al. (2006), estuaries are of great interest for studying copepod population dynamics, because they are extremely dynamic and heterogeneous ecosystems, subject to strong fluctuations in environmental parameters. In the Amazon estuaries of Brazil, knowledge about copepod communities is relatively scarce. There is little information published on the community structure of these organisms (Krumme and Liang 2004, Magalhães et al. 2006). Therefore, the purpose of the present study was to assess the copepod composition and characterize seasonal density and dominance patterns as well as ecological indexes of their populations related to salinity variations in the Curuçá estuary, northern Brazil.

\section{STUDY AREA}

The Curuçá estuary is located on the Amazon littoral, north-eastern Pará State, near the city of Curuçá $\left(00^{\circ} 43^{\prime} 48^{\prime \prime} \mathrm{S}\right.$ and $\left.47^{\circ} 51^{\prime} 06^{\prime \prime} \mathrm{W}\right)$ and is part of the second largest contiguous mangrove unit of the world (Kjerfve and Lacerda 1993). The predominant coastal vegetation along the margins of the Curuçá estuary is represented by three genders of mangroves: Avicennia, Rhizophora and Laguncularia. The main hydrodynamic feature is a maximum tidal height of $5 \mathrm{~m}$ in a semi-diurnal cycle, although this range can reach $6 \mathrm{~m}$ during the equinoctial spring tides (DHN 2008). The region is characterized by a tropical hot and humid climate, which presents a pronounced seasonality with the dry season, lasting from June to December (ANA 2006). Mean air temperature is $27^{\circ} \mathrm{C}$, with annual rainfall values exceeding $2.000 \mathrm{~mm}$ (CCS 2006).

\section{MATERIALS AND METHODS}

\section{SAMPling Strategy AND LABORATORY Methods}

To assess spatial and temporal patterns of the copepods, samples were collected at four stations in the inner part of the Curuçá estuary (Fig. 1) in the neap tides of July, November and December 2003 (dry season) and January, March and May 2004 (rainy season). The plankton tows were accomplished at sub-surface water level, using a conical-cylindrical net $(200 \mu \mathrm{m}$ mesh size, $50 \mathrm{~cm}$ diameter and $1.8 \mathrm{~m}$ in length) fitted with a flowmeter to estimate the volume of water filtered through the net. All samples collected were immediately conditioned in plastic bottles and preserved in 5\% formalin, buffered with sodium tetra-borate. Only one tow was made at each station, performed with a boat for approximately $3 \mathrm{~min}$ at a speed of 1.5 knots, producing a total of 24 plankton samples. Measurements of sub-surface water conductivity were accomplished in situ using an electronic conductivimeter (Orion, Model 105). Salinity was later obtained through the transformation of conductivity values.

Due to the great amount of organisms present in the samples, aliquots were taken using a Folsom Plankton Sample Splitter according to the degree of organism concentration. Under a stereoscopic microscope the copepod individuals were identified to the lowest possible taxonomic level and counted, using appropriate identification keys (Trégouboff and Rose 1957, Boltovskoy 1981, Bradford-Grieve et al. 1999).

\section{Ecological Indexes and Statistical Analyses}

The quantitative data obtained for each sample was used to calculate absolute and relative density, as well as ecological indexes (diversity and evenness). The copepod diversity was calculated using the Shannon-Wiener's index $\left(H^{\prime}\right.$, as log to the base 2$)$ and evenness was calculated through Pielou's index ( $J$, as log to the base 2).

Additionally, to visualize and compare diversity profiles in different seasonal periods and between sampling months, K-dominance curves (Lambshead et al. 1983) were plotted. For this, species were ranked from 1 to $\mathrm{x}$, with species 1 representing the largest percentage of total individuals, species 2 the second largest, etc., plotted against cumulative dominance.

When necessary, the raw data of total and principal taxa density (ind. $\mathrm{m}^{-3}$ ) of copepods, as well as ecolog- 


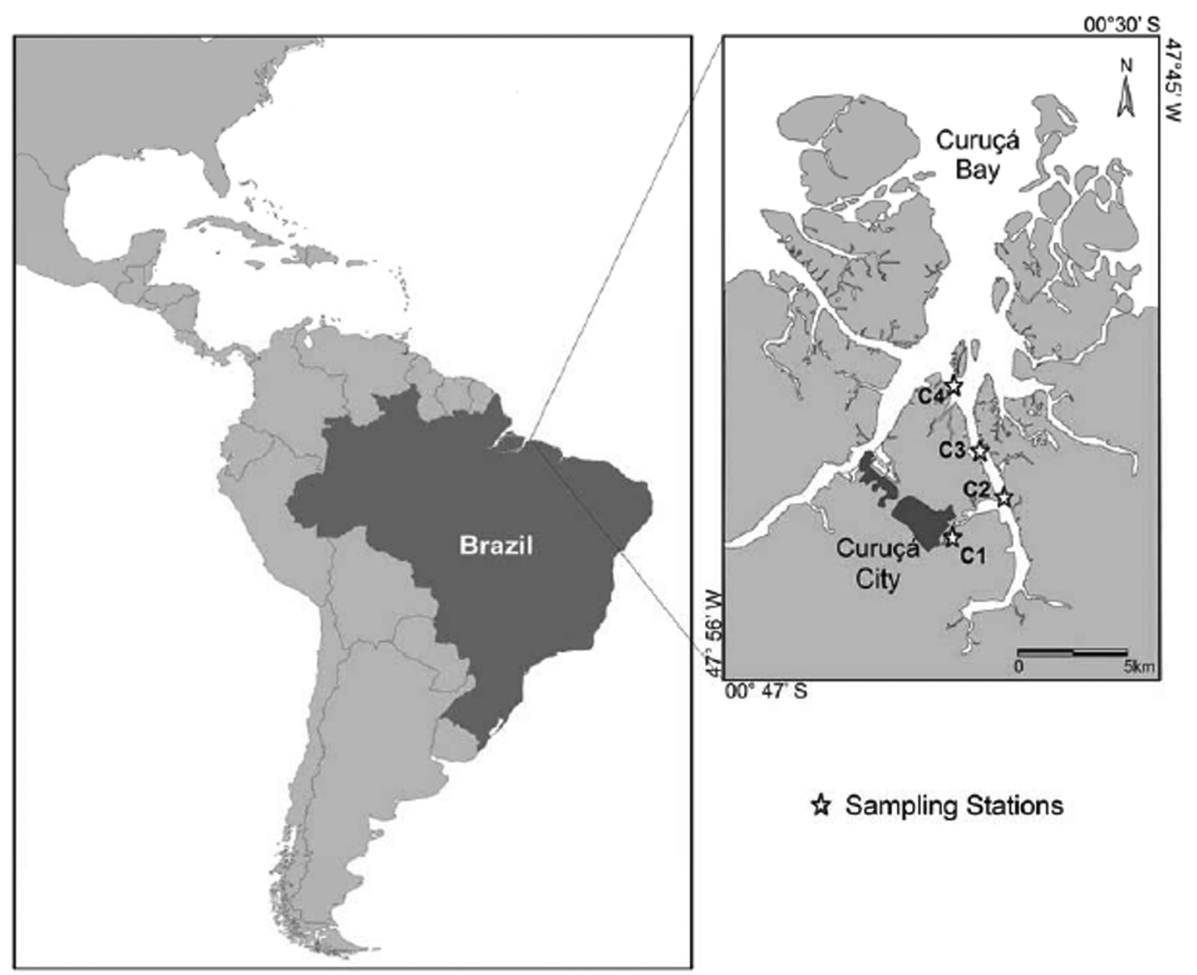

Fig. 1 - Geographical localization showing the study area with the four sampling stations (C1, C2, C3 and C4) in the Curuçá estuary (Pará, Brazil). (Modified from Hercos and Giarrizzo 2007).

ical indexes, were $\log (x+1)$-transformed so that their distributions approached normality. The assumption of homogeneity of variance was tested using Bartlett's Chisquare test. Where the variances were homogeneous, one-way ANOVA with a 5\% significance level was used to determine possible seasonal and spatial differences in density, diversity and evenness of copepods. However, when variances were heterogeneous, the non-parametric Mann-Whitney $U$-test was applied (Zar 1999).

Spearman's correlation coefficient was calculated to characterize the relationships between salinity, copepod density and ecological indexes. All these statistical analyses were conducted employing the program STATISTICA, version 5, computer software package.

To investigate similarities among sampling months, hierarchical agglomerative cluster analysis and nonmetric multidimensional scaling (MDS) ordination were computed using the Bray-Curtis similarity index and $\log (x+1)$-transformed density data, performed through the PRIMER (Plymouth Routines Multivariate Ecological Research) software package, version 6, following Clarke and Warwick (1994).

\section{RESULTS}

\section{SALINITY AND RAINFALL}

In the present study, salinity, as well as density and ecological indexes, did not show spatially significant differences $(p>0.05)$ among the four sampled stations. Thus, reported values for each sampling month were pooled and have been evaluated on seasonal scales (dry/ rainy seasons).

Results showed a significant seasonal variation in sub-surface water salinity (Mann-Whitney $U$-test $=0.0$, $p<0.05)$. The lowest value $(7.2 \pm 0.1$; average \pm standard deviation) was registered in March (rainy season), while the highest value $(39.2 \pm 1.8)$ was recorded in November (dry season) (Fig. 2). When compared to salinity, an opposite trend was observed for the total monthly rainfall, with the rainy season presenting the highest values (from 148.7 to $502.9 \mathrm{~mm}$ ). In the $\mathrm{Cu}$ ruçá estuary, monthly changes in salinity were mainly influenced by rainfall differences (Fig. 2). 


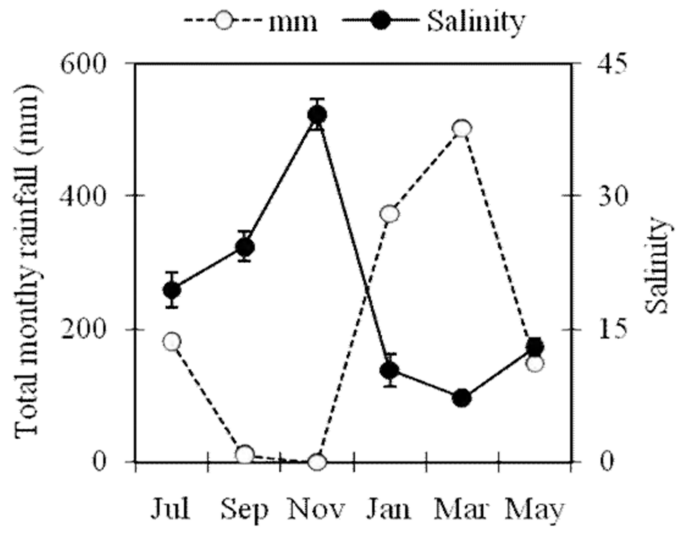

Fig. 2 - Seasonal variation of salinity (means $\pm \mathrm{SD}$ ) in relation to total monthly rainfall (ANA 2006) in the Curuçá estuary.

\section{COPEPOD COMPOSITION AND DENSITY}

A total of 30 Copepoda taxa were identified (Table I). Among them, eighteen could be assigned to species level and the others were either not identified to the species level or unidentified. Monthly and seasonal distributions of copepod densities were presented (Figs. 3b, 5c and Table I). Acartia tonsa (Dana, 1849) was the taxa most represented throughout the entire study period, reaching up to $91.5 \%$ of the total copepod density registered in May, followed by Acartia lilljeborgii (Giesbrecht, 1889) with $23.4 \%$ in September, Subeucalanus pileatus (Giesbrecht, 1888) with $17.4 \%$ in November and Paracalanus quasimodo (Bowman, 1971) with $14.9 \%$ in July.

Among the main taxa, A. tonsa (ANOVA, $F=$ 22.1, $p<0.001$ ) and $S$. pileatus (ANOVA, $F=17.6$, $p<0.001)$ showed significant seasonal differences in density patterns. Seasonal differences were also observed for total copepod density (ANOVA, $F=17.6$, $p<0.05$ ). Monthly results of the copepod density, diversity and evenness were plotted against salinity (Fig. 3). The Spearman coefficient showed a significant relationship between salinity and densities of $A$. tonsa $(r s=-0.59, p<0.05)$ and $S$. pileatus $(r s=0.54$, $p<0.05)$. On the other hand, there was no significant correlation in the case of A. lilljeborgii ( $r s=0.40$, $p>0.05)$, P. quasimodo ( $r s=0.30, p>0.05$ ) and total copepod densities $(r s=0.37, p>0.05)$. In addition to the correlations between salinity and copepods diversity $(r s=0.73, p<0.0001)$ and evenness $(r s=0.65$, $p<0.001)$ were all significant and positive.
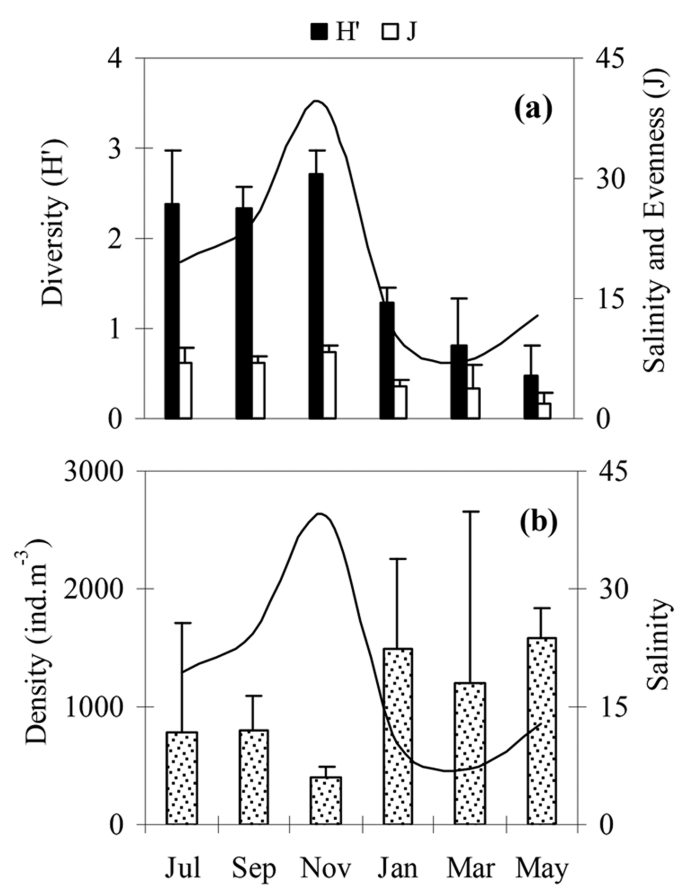

Fig. 3 - Monthly means ( \pm SD) in copepod ecological indexes (a) and total copepod density (b) registered in the Curuçá estuary. These data were plotted against salinity (line).

\section{COMMUNity STRUCTURE}

Consistent seasonal patterns of diversity and evenness were evident throughout the sampling periods (Fig. 3a), and the lowest values for all of these indexes were recorded in May.

Highly significant statistical differences were found in diversity (ANOVA, $F=79.4, p<0.00001$ ) between the two seasons. The values increased during the dry season and decreased in the rainy season, with average values oscillating between $0.47 \pm 0.33$ (May) and $2.72 \pm 0.25$ (November) bits.ind ${ }^{-1}$. The accentuated decrease in diversity during rainy months was accompanied by high total copepod densities. An opposite situation was detected for dry months. Similarly, evenness (ANOVA, $F=37.2, p<0.00001$ ) showed significant seasonal difference, with average values ranged from $0.17 \pm 0.11$ (May) to $0.75 \pm 0.05$ (November).

$\mathrm{K}$-dominance curves also revealed a gradual decline in diversity throughout the rainy months (Fig. 4b). The curves for these months exhibited a higher dominance but lower diversity. An opposite behavior occurred in the dry season (Fig. 4a). K-dominance curves still exhibited marked differences in diversity and relative species 
TABLE I

Taxonomic composition, absolute (means \pm SD) and relative densities of copepods collected during dry (July, September and November) and rainy seasons (January, March and May) in the Curuçá estuary.

\begin{tabular}{|c|c|c|c|c|}
\hline Taxa & Dry & $\%$ & Rainy & $\%$ \\
\hline Acartia (juveniles) & $1.5 \pm 2.5$ & 0.06 & $0 \pm 0$ & 0 \\
\hline Acartia tonsa Dana, 1849 & $1097.1 \pm 729.0$ & 41.74 & $4853.8 \pm 814.9$ & 85.44 \\
\hline Acartia lilljeborgii Giesbrecht, 1889 & $435.1 \pm 275.6$ & 16.55 & $208.7 \pm 99.9$ & 3.67 \\
\hline Acartia sp. & $0.5 \pm 0.8$ & 0.02 & $0 \pm 0$ & 0 \\
\hline Paracalanus quasimodo Bowman, 1971 & $306.0 \pm 132.4$ & 11.64 & $217.9 \pm 231.4$ & 3.84 \\
\hline Parvocalanus crassirostris (F. Dahl, 1894) & $10.5 \pm 4.4$ & 0.40 & $4.1 \pm 7.0$ & 0.07 \\
\hline Pseudodiaptomus marshi Wright, 1936 & $3.6 \pm 5.7$ & 0.14 & $21.7 \pm 12.0$ & 0.38 \\
\hline Pseudodiaptomus richardi (F. Dahl, 1894) & $0.5 \pm 0.8$ & 0.02 & $9.0 \pm 8.0$ & 0.16 \\
\hline Pseudodiaptomus acutus (F. Dahl, 1894) & $58.4 \pm 31.5$ & 2.22 & $50.3 \pm 62.9$ & 0.89 \\
\hline Pseudodiaptomus sp. & $34.5 \pm 25.4$ & 1.31 & $26.2 \pm 14.7$ & 0.46 \\
\hline Labidocera (juveniles) & $104.4 \pm 121.5$ & 3.97 & $0 \pm 0$ & 0 \\
\hline Labidocera fluviatilis F. Dahl, 1894 & $25.8 \pm 26.9$ & 0.98 & $81.8 \pm 132.7$ & 1.44 \\
\hline Calanopia americana F. Dahl, 1894 & $5.0 \pm 5.7$ & 0.20 & $2.7 \pm 4.0$ & 0.05 \\
\hline Subeucalanus pileatus (Giesbrecht, 1888) & $159.1 \pm 104.9$ & 6.05 & $28.5 \pm 23.6$ & 0.50 \\
\hline Centropages furcatus (Dana, 1849) & $17.3 \pm 3.0$ & 0.66 & $17.6 \pm 18.1$ & 0.31 \\
\hline Temora longicornis (Müller, 1792) & $10.0 \pm 4.3$ & 0.38 & $0 \pm 0$ & 0 \\
\hline Candacia sp. & $0.9 \pm 1.5$ & 0.03 & $0 \pm 0$ & 0 \\
\hline Corycaeus speciosus Dana, 1849 & $2.3 \pm 3.9$ & 0.09 & $5.2 \pm 9.0$ & 0.09 \\
\hline Corycaeus latus Dana, 1849 & $0 \pm 0$ & 0 & $0.7 \pm 1.2$ & 0.01 \\
\hline Corycaeus lautus Brady, 1883 & $7.8 \pm 8.7$ & 0.30 & $21.2 \pm 36.8$ & 0.37 \\
\hline Corycaeus sp. & $0 \pm 0$ & 0 & $1.6 \pm 2.9$ & 0.03 \\
\hline Oithona spp. & $23.5 \pm 12.8$ & 0.90 & $101.2 \pm 93.1$ & 1.78 \\
\hline Oncaea sp. & $4.8 \pm 7.8$ & 0.18 & $0 \pm 0$ & 0 \\
\hline Cymbasoma sp. & $13.9 \pm 23.6$ & 0.53 & $0.7 \pm 1.2$ & 0.01 \\
\hline Tisbe sp. & $124.0 \pm 67.3$ & 4.72 & $8.7 \pm 10.1$ & 0.15 \\
\hline Euterpina acutifrons (Dana, 1847) & $82.2 \pm 31.6$ & 3.13 & $12.7 \pm 12.2$ & 0.22 \\
\hline Clytemnestra scutellata Dana, 1847 & $0.1 \pm 0.1$ & $\mathrm{~b}$ & $0 \pm 0$ & 0 \\
\hline Harpacticoida $^{\mathrm{a}}$ & $0 \pm 0$ & 0 & $6.5 \pm 9.8$ & 0.11 \\
\hline Parasitic Copepoda $^{a}$ & $0.3 \pm 0.5$ & 0.01 & $0 \pm 0$ & 0 \\
\hline Copepoda $^{\text {a }}$ (adults and juveniles) & $99.0 \pm 47.4$ & 3.77 & $0 \pm 0$ & 0 \\
\hline
\end{tabular}

${ }^{\mathrm{a}}$ Organisms identified to group level; ${ }^{\mathrm{b}}$ Less than $0.01 \%$.

density distributions among both dry and rainy seasons (Fig. 4c).

The cluster and MDS analyses performed on monthly density of taxa registered during the present study clearly showed the temporal differences in the copepod community at the Curuçá estuary. The results indicated the presence of two distinct groups at $65 \%$ similarity (Fig. 5a, b). The first group comprised the months of July, September and November (dry season). During these three sampling months, a gradual reduction in the $A$. tonsa densities was verified following an increase in salinity. On the other hand, the second group, which corresponded to January, March and May (rainy season) showed a considerable increase in $A$. tonsa contributions on total copepod density, while salinity values decreased (Fig. 5c). When comparing density distribution pattern of $A$. tonsa with that observed for the others main taxa (A. lilljeborgii, S. pileatus and P. quasimodo), an oppo- 

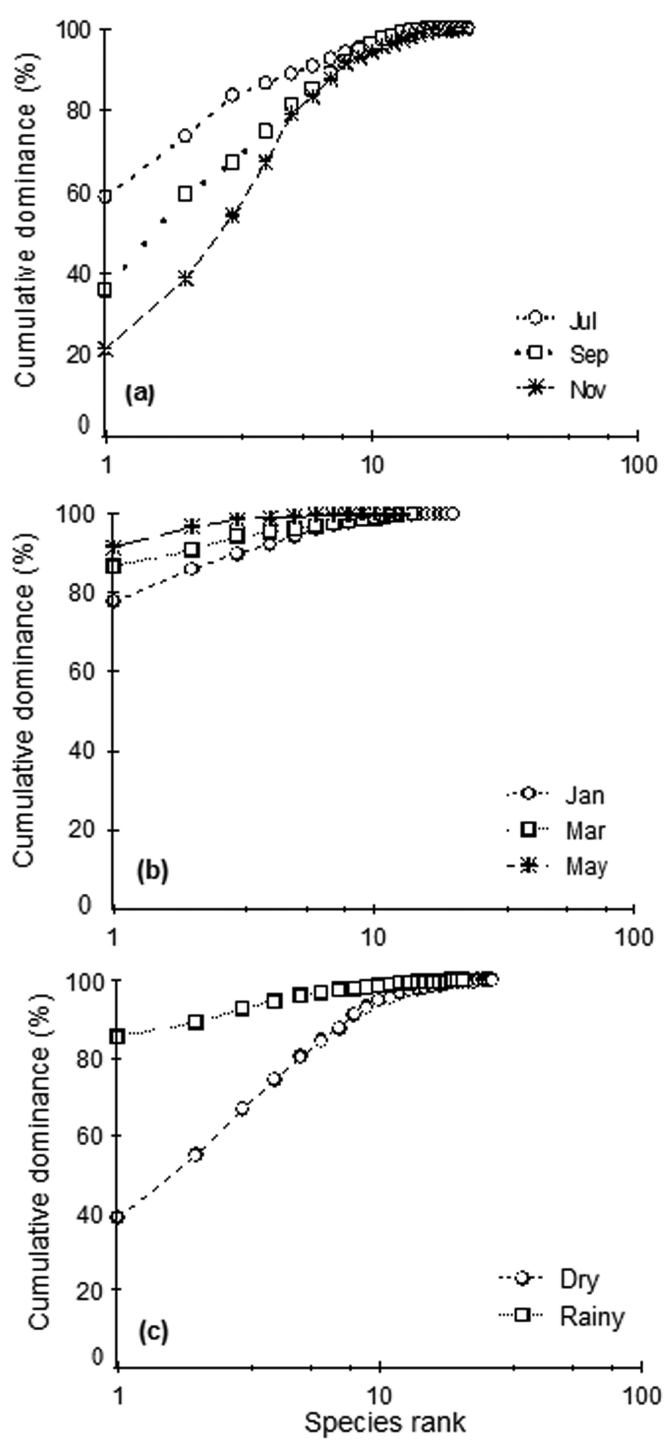

Fig. 4 - Cumulative dominance curves of copepods for dry (a) and rainy (b) sampling months and for the two seasons (c) in the Curuçá estuary.

site situation was verified. For the former, the highest density was reported during the rainy season (group II), while for the last three species these values were greater in the dry season (group I).

\section{DISCUSSION}

Sub-surface water salinity was characterized by pronounced seasonality, with the largest values found in the dry season. Tropical estuarine ecosystems in Brazil (Porto and Fonteles-Filho 1986, Thüllen and Berger 2000) and worldwide (Blaber 2002, Capo et al. 2006,
Lam-Hoai et al. 2006) seasonal changes in salinity are mainly influenced by rainfall distribution between the seasons. In general, decreases in pluviometric precipitation during the dry season caused gradual decreases in river discharges and land run-off. Consequently, it was possible to verify increases in salinity in the inner parts of these estuaries due to the input of a larger volume of coastal and marine waters in those environments.

The distributional pattern observed for total copepod density, with the highest values registered in the rainy season, was in part related to the behavior of $A$. tonsa which was the species most represented as was also reported in many other estuarine systems (Palomares-García and Gómez-Gutiérrez 1996, Hoffmeyer and Torres 2001, Vieira et al. 2003). This calanoid planktonic copepod is a cosmopolitan species, common in estuaries of the Atlantic coast of South and North America (Bradford-Grieve et al. 1999), and is considered an important zooplankton component in most of these estuaries showing a high degree of tolerance for environmental change.

The significant and negative correlation between salinity and density of $A$. tonsa, evidenced the species preference for estuarine waters that show mesohaline characteristics $(18.0>$ surface salinity $>5.0)$, according to the Venice system of classification of saline waters (Anonymous 1958). Intraspecific tolerance to low and moderate salinities could explain the higher numerical representativeness of $A$. tons $a$ during the entire rainy season, when salinities were not accentuated.

Numerous completed studies on estuaries describe the reduction in copepod species density during the rainy season (Lansac-Tôha 1985, Mwaluma et al. 2003, Osore et al. 2004, among others). An opposite trend was verified for $A$. tonsa in the Curuçá estuary. This observation is consistent with the one described by Ara (1998), who studied the temporal variability and production of copepods in the Cananéia Lagoon estuarine system (São Paulo, Brazil) and pointed out that the highest $A$. tonsa densities were registered in February, which represents the rainy season.

For S. pileatus, a species of warm coastal and shelf waters of the tropical and subtropical regions of the southwest Atlantic (Björnberg 1981), the correlation between salinity and density was significant and positive. 
(a) Bray-Curtis Similarity (\%)

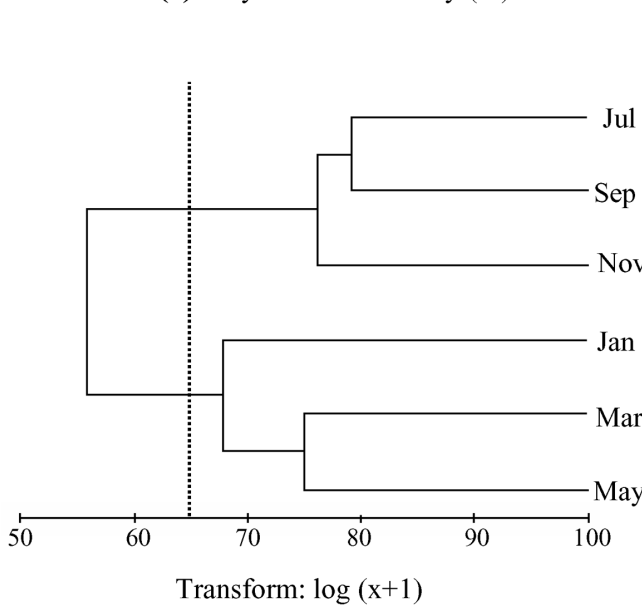

A. tonsa (c) Percentage

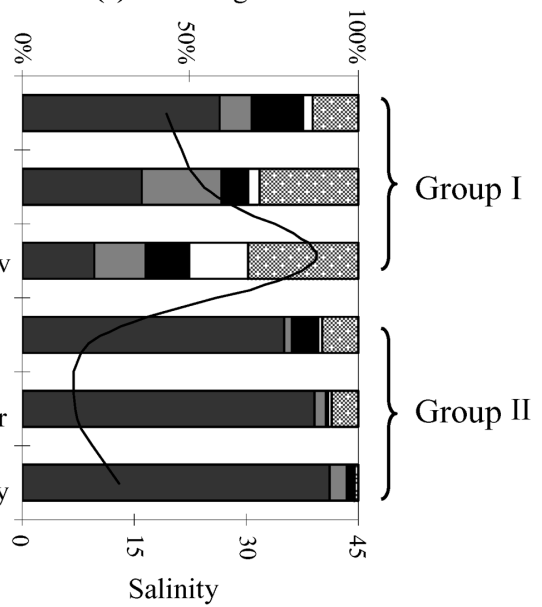

S. pileatus

Others

(b) MDS

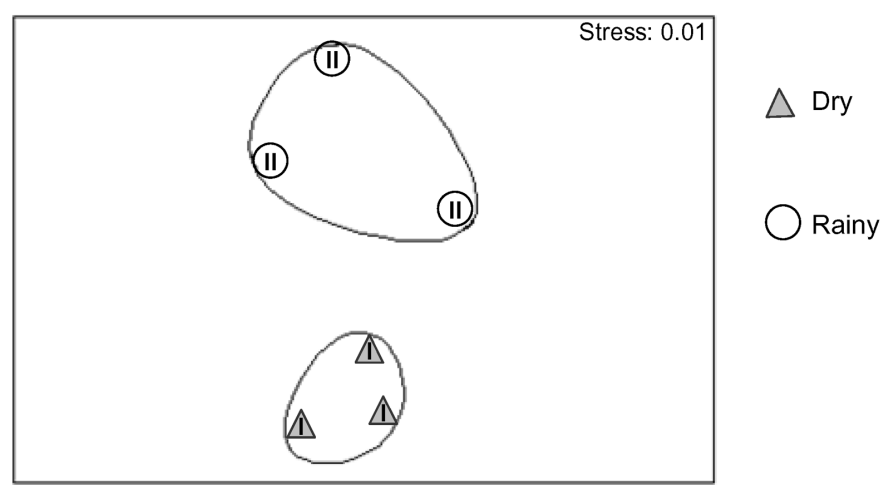

Fig. 5 - Cluster (a) and MDS (b) analyses based on copepod taxa densities during dry (group I) and rainy (group II) sampling months in the Curuçá estuary. Percentage of the main taxa density (c). These data were plotted against salinity (line).

The highest densities recorded in the dry season suggest that the presence of this species in the studied area depends on the recruitment from the adjacent coastal zone.

A. lilljeborgii is the predominant species in various Brazilian estuaries (Nascimento-Vieira and Eskinazi Sant'Anna 1989, Dias 1999, Silva et al. 2003). However, in the present study it's contribution to monthly and seasonal copepod density was not expressive if compared with $A$. tonsa. As observed by Sterza and Fernandes (2006), evaluating the zooplankton community of the Vitória Bay estuarine system (southeastern Brazil), no significant correlation between $A$. lilljeborgii density and salinity was found.

Dominant in most tropical and subtropical coastal areas (Lopes et al. 1999, Eskinazi-Sant'Anna and Björnberg 2006), P. quasimodo together with A. lilljeborgii were the only main taxa that did not show a consistent seasonal pattern in terms of density. Moreover, the oceanic copepods Corycaeus speciosus (Dana, 1849), Corycaeus latus (Dana, 1849), Corycaeus lautus (Brady, 1883) and Cymbasoma sp. were also recorded, although they were not numerically representative in the present study.

At the Curuçá estuary, the ecological indexes showed significant seasonal variations, which were influenced by oscillations in salinity. The copepod community presented low and moderate diversity values in rainy and dry seasons, respectively. A decrease in cope- 
pod diversity in rainy months was related to an increase of $A$. tonsa contribution for the total copepod density. $A$. tonsa density was increased with the decrease in salinity. This may have occurred due to the reduced contribution of coastal and marine waters during rainy months. The opposite was detected for dry months. Copepod diversity values obtained in the Curuçá estuary tended to be greater than those observed in other estuaries worldwide (Hsieh and Chiu 1997, Islam et al. 2006).

Evenness presented a similar trend to diversity, with both parameters increasing with salinity values. The decline of these parameters in the rainy season indicated the presence of lower "stability" condition for the estuary, when compared with the dry season. Thus, the situation in the latter is completely different. The copepod community structure is relatively more diverse and the salinity influence on this community is greatest.

Monthly and seasonal changes in the balance of relative density of four main copepod species as visualized in the K-dominance curves, directly affect the behavior of ecological indexes. In particular, changes in $A$. tonsa contribution in the studied period were strongly responsible for alterations in these indexes. The present study has shown a clear seasonal pattern in density, diversity and evenness of copepod community and salinity values, which had been confirmed by plots of cluster and multidimensional scaling (MDS). Therefore, the studied area may be considered spatially uniform and seasonally heterogeneous in relation to these parameters. Nevertheless, further investigations on biomass and copepod community production in the Curuçá estuary should be assessed for providing a better understanding of the trophic structure of this ecosystem.

\section{ACKNOWLEDGMENTS}

We are grateful to Hector Hernán Martinez Baeza for English improvements to the manuscript. This work was supported by Conselho Nacional de Desenvolvimento Científico e Tecnológico (CNPq) (Processes \#23116.000272/2002-88, \#552126/05-5 and \#563967/ 2005-6). The authors Luci Cajueiro Carneiro Pereira and Rauquírio Marinho da Costa would like to thank CNPq (Brazil) for their research grants (\#304392/2005-7 and \#308953/2006-1, respectively).

\section{RESUMO}

O presente estudo teve como objetivo principal avaliar a variação sazonal na estrutura da comunidade dos copépodos durante os meses de julho, setembro e novembro de 2003 (período seco) e janeiro, março e maio de 2004 (período chuvoso) no estuário do Curuçá, Norte do Brasil. As amostras foram coletadas nas marés de quadratura com auxílio de uma rede de plâncton com $200 \mu \mathrm{m}$ de abertura de malha, rebocada por meio de uma pequena embarcação a motor. As medidas de condutividade da água foram realizadas in situ utilizando-se um condutivímetro eletrônico e a salinidade foi posteriormente obtida através da transformação dos valores de condutividade. Os valores de salinidade variaram sazonalmente de 7,2 $\pm 0,1$ a 39, $2 \pm 1,8$ (média \pm desvio padrão), tendo sido principalmente influenciados pelas diferenças nas taxas de precipitação entre os períodos de amostragem estudados. Foram identificados no total 30 táxons, com Acartia tonsa constituindo a espécie mais representativa durante todo o período de estudo, seguida por Acartia lilljeborgii, Subeucalanus pileatus e Paracalanus quasimodo. Durante este trabalho, os valores de densidade, índices ecológicos e dominância das espécies de copépodos apresentaram um padrão sazonal claro, mostrando que a área estudada pode ser considerada sazonalmente heterogênea em relação a estes parâmetros investigados.

Palavras-chave: copépodos, salinidade, índices ecológicos, mudanças sazonais, Brasil.

\section{REFERENCES}

Agência Nacional de Águas (ANA). 2006. Climatological data (1990-2004). Agência Nacional de Águas, Brasília, DF, Brasil.

AnONYmous. 1958. Venice system. Supplement to the Symposium on the classification of brackish waters. Arch Oceanogr Limnol 11 (Suppl): 1-248.

ARA K. 1998. Variabilidade temporal e produção dos copépodos no complexo estuarino-lagunar de Cananéia, São Paulo, Brasil. Ph.D. Thesis, Universidade de São Paulo, Brasil. 308 pp.

ARA K. 2004. Temporal variability and production of the planktonic copepod community in the Cananéia Lagoon estuarine system, São Paulo, Brazil. Zool Stud 43: 179186.

Beyst B, Buysse D, Dewicke A And Mees J. 2001. Surf zone hyperbenthos of Belgian sandy beaches: seasonal patterns. Est Coast Shelf Sci 53: 877-895. 
BJÖRNBERG TKS. 1981. Copepoda. In: BoltovSKOY D (Eds), Atlas del Zooplancton del Atlantico Sudoccidental y Métodos de Trabajo con el Zooplancton Marino, Mar del Plata: Instituto Nacional de Investigación y Desarrollo Pesquero, p. 587-679.

BLABER SJM. 2002. Fish in hot water: the challenges facing fish and fisheries research in tropical estuaries. J Fish Biol 61: $1-20$.

Boltovskoy D. 1981. Atlas del zooplancton del Atlántico Sudoocidental y métodos de trabajos con el zooplancton marino, Mar del Plata: Instituto Nacional de Investigación y Desarrollo Pesquero, 936 p.

BradFord-Grieve JM, Markhaseva EL, Rocha CEF AND ABIAHY B. 1999. Copepoda. In: Boltovskoy D (Eds), South Atlantic Zooplankton, Netherlands: Backhuys, p. 869-1098.

Capo S, Sottolichio A, Brenon I, Castaing P And FERRY L. 2006. Morphology, hydrography and sediment dynamics in a mangrove estuary: the Konkoure Estuary, Guinea. Mar Geol 230: 199-215.

Cervetto G, Gaudy R and Pagano M. 1999. Influence of salinity on the distribution of Acartia tonsa (Copepoda, Calanoida). J Exp Mar Biol Ecol 239: 33-45.

Champalbert G And Pagano M. 2002. Copepod feeding in a tuna fishery area of the tropical Atlantic Ocean. CR Biol 325: 171-177.

Clarke KR AND WarWick RM. 1994. Changes in marine communities: an approach to statistical analysis and interpretation, United Kingdom: Plymouth Marine Laboratory, $144 \mathrm{p}$.

COORDENAdORIA DE COMUNICAÇÃo SOCIAL do GOVERno do Estado do ParÁ (CCS). 2006. Município de Curuçá. Produced by Start Comunicação e Informática. Available at http://www.governodopara.pa.gov.br/conhecaopara/curucal.asp.

David V, Sautour B and Chardy P. 2007. Successful colonization of the calanoid copepod Acartia tonsa in the oligo-mesohaline area of the Gironde estuary (SW France) - Natural or anthropogenic forcing? Est Coast Shelf Sci 71: 429-442.

DIAS CO. 1999. Morphological abnormalities of Acartia lilljeborgi (Copepoda, Crustacea) in the Espírito Santo Bay (ES, Brazil). Hydrobiologia 394: 249-251.

Diretoria de Hidrografia E NAVEgAÇÃO (DHN). 2008. Tábua das marés para 2008. Fundeadouro de Salinópolis (Estado do Pará). Available at http://www.mar.mil.br/ dhn/tabuas.
Escribano R AND Hidalgo P. 2000. Spatial distribution of copepods in the North of the Humboldt Current region off Chile during coastal upwelling. J Mar Biol Assoc UK 80: $283-290$

ESKINAZI-SANT'ANNA EM AND BJÖRNBERG TKS. 2006. Seasonal dynamics of mesozooplankton in Brazilian coastal waters. Hydrobiologia 563: 253-268.

Evjemo JO, KJell IR AND Olsen Y. 2003. Copepods as live food organisms in the larval rearing of halibut larvae (Hippoglossus hippoglossus L.) with special emphasis on the nutritional value. Aquaculture 227: 191-210.

FRONEMAN PW. 2004. Zooplankton community structure and biomass in a southern African temporarily open/closed estuary. Est Coast Shelf Sci 60: 125-132.

HASSEL A. 1986. Seasonal changes in zooplankton composition in the Barents Sea, with special attention to Calanus spp. (Copepoda). J Plankton Res 8: 329-339.

Hercos AP And Giarrizzo T. 2007. Pisces, Syngnathidae, Hippocampus reidi: filling distribution gaps. Check List 3: 287-290.

HofFMeyer MS AND TORRES ER. 2001. Morphometric variables and individual volume of Eurytemora americana and Acartia tonsa females (Copepoda, Calanoida) from the Bahía Blanca estuary, Argentina. Hydrobiologia 459: 73-82.

HSIEH C-H AND CHIU T-S. 1997. Copepod abundance and species composition of Tanshui River Estuary and adjacent waters. Acat Zool Taiwan 8: 75-83.

ISLAM MDS, UEDA H AND TANAKA M. 2006. Spatial and seasonal variations in copepod communities related to turbidity maximum along the Chikugo estuarine gradient in the upper Ariake Bay, Japan. Est Coast Shelf Sci 68: $113-126$.

KJERFVE B AND LACERDA LD. 1993. Mangroves of Brazil. In: LACERDA LD (Eds), Conservation and Sustainable Utilization of Mangrove Forest in Latin America and Africa Regions. Part I - Latin America. Mangrove Ecosystem Technical Report No. 2, Okinawa: International Tropical Timber Organization/International Society for Mangrove Ecosystems, p. 245-272.

KRUMme U AND Liang T-H. 2004. Tidal-induced changes in a copepod-dominated zooplankton community in a macrotidal mangrove channel in Northern Brazil. Zool Stud 43: 404-414.

Lambshead PJD, Platt HM and Shaw KM. 1983. The detection of differences among assemblages of marine benthic species based on an assessment of dominance and diversity. J Nat Hist 17: 859-874. 
Lam-Hoai T, Guiral D ANd Rougier C. 2006. Seasonal change of community structure and size spectra of zooplankton in the Kaw River estuary (French Guiana). Est Coast Shelf Sci 68: 47-61.

LANSAC-TÔHA FA. 1985. Ecologia do zooplâncton do estuário do Rio Una do Prelado (São Paulo, Brasil). Ph.D. Thesis, Universidade de São Paulo, Brazil. 195 p.

Lawrence D, Valiela I And Tomasky G. 2004. Estuarine calanoid copepod abundance in relation to season, salinity, and land-derived nitrogen loading, Waquoit Bay, MA. Est Coast Shelf Sci 61: 547-557.

Li KZ, Yin JQ, HuAng LM AND TAN YH. 2006. Spatial and temporal variations of mesozooplankton in the Pearl River estuary, China. Est Coast Shelf Sci 67: 543-552.

Lopes RM, Brandini FP and Gaeta SA. 1999. Distribution patterns of epipelagic copepods off Rio de Janeiro (SE, Brazil) in summer 1991/1992 and winter 1992. Hydrobiologia 411: 161-174.

López-Ibarra GA and Palomares-García R. 2006. Estructura de la comunidad de copépodos en Bahía Magdalena, México, durante El Niño 1997-1998. Rev Biol Mar Oceanogr 411: 63-76.

Magalhães A, Costa RM, Liang T-H, Pereira LCC AND RIBEIRO MJS. 2006. Spatial and temporal distribution in density and biomass of two Pseudodiaptomus species (Copepoda: Calanoida) in the Caeté River Estuary (Amazon region - North of Brazil). Braz J Biol 66: 421-430.

Mwaluma J, Osore M, Kamau J and Wawiye P. 2003. Composition, abundance and seasonality of zooplankton in Mida Creek, Kenya. Western Indian Ocean J Mar Sci 2: $147-155$.

NASCIMENTO-VIEIRA DA AND ESKINAZI SANT'ANNA EM. 1989. Composição do zooplâncton no estuário do Rio Timbó (Pernambuco - Brasil). Trabhs Oceanogr Univ Fed Pernambuco 20: 77-98.

Osore MKW, Mwaluma JM, Fiers F and Daro MH. 2004. Zooplankton composition and abundance in Mida Creek, Kenya. Zool Stud 43: 415-424.

PAlOMARES-GARCÍA R AND GóMEZ-GutiÉRREZ J. 1996. Copepod community structure at Bahia Magdalena, Mexico during El Niño 1983-84. Est Coast Shelf Sci 43: 583-595.

Parsons TR, TAKahashi M AND Hargrave B. 1984. Biological Oceanographic Processes, Oxford: Pergamon Press, $332 \mathrm{p}$.
PAYNE MF AND RipPINGALE RJ. 2001. Effects of salinity, cold storage and enrichment on the calanoid copepod Gladioferens imparipes. Aquaculture 201: 251-262.

Porto HLR And Fonteles-Filho AA. 1986. Estudo de densidade e biomassa de camarões do gênero Penaeus, na ilha de São Luiz, Estado do Maranhão. Bol Lab Hidrobiol São Luís 7: 42-70.

RipPINGALE RJ AND HodgKIn EP. 1977. Food availability and salinity tolerance in a brackish water copepod. Aust J Mar Freshw Res 28: 1-7.

SARKAR SK AND CHOUdHURY A. 1998. Distribution of inshore copepod of the Bay of Bengal off Sagar Island: A multivariate analysis. Trop Ecol 29: 146-158.

SChIPP GR, Bosmans JMP And Marshall AJ. 1999. A method for hatchery culture of tropical calanoid copepods, Acartia spp. Aquaculture 174: 81-88.

SchWAmborn R, Voss M, EKaU W AND SAInT-PaUl U. 1999. Stable isotope composition of particulate organic matter and zooplankton in North-East Brazilian shelf water. Arch Fish Mar Res 47: 201-210.

Silva TA, Neumann-Leitão S, Schwamborn R, GusMÃo LMO AND NASCIMENTO-VIEIRA DA. 2003. Diel and seasonal changes in the macrozooplankton community of a tropical estuary in Northeastern Brazil. Rev Bras Zool 20: 439-446.

Soetaert K AND RiJswiJK VAN P. 1993. Spatial and temporal patterns of the zooplankton in the Westerschelde estuary. Mar Ecol Prog Ser 97: 47-59.

SOMmer U AND STIBOR H. 2002. Copepoda - CladoceraTunicata: the role of three major mesozooplankton groups in pelagic food webs. Ecol Res 17: 161-174.

Sommer U, Stibor H, Katechakis A, Sommer F AND HANSEN T. 2002. Pelagic food web configurations at different levels of nutrient richness and their implications for the ratio fish production: primary production. Hydrobiologia 484: 11-20.

STERZA JM AND FERNANDES LL. 2006. Zooplankton community of the Vitória Bay estuarine system (Southeastern Brazil). Characterization during a three-year study. Braz J Oceanogr 54: 95-105.

ThÜllen N AND Berger U. 2000. A comparative examination of environmental factors at patchy mangrove seedling stands on the peninsula of Bragança, Northern Brazil. Ecotropica 6: 1-12.

Trégouboff G And Rose M. 1957. Manuel de Planctonologie Méditerranée, Paris: Centre National de la Recherche Scientifique, $587 \mathrm{p}$. 
URIARTE I AND Villate F. 2005. Differences in the abundance and distribution of copepods in two estuaries of the Basque coast (Bay of Biscay) in relation to pollution. J Plankton Res 27: 863-874.

Vieira L, Azeiteiro U, Ré P, PAstorinho R, MARQues JC AND MORGADo F. 2003. Zooplankton distribution in a temperate estuary (Mondego estuary southern arm: Western Portugal). Acta Oecol 24: 163-173.
YÁÑEZ ARANCIBIA A, LARA-DOMINGUEZ AL AND DAY JW. 1993. Interactions between mangrove and seagrass habitats mediated by estuarine nekton assemblages: coupling of primary and secondary production. Hydrobiologia 264: 1-13.

ZAR JH. 1999. Biostatistical Analysis, $4^{\text {th }}$ ed., Upper Saddle River: Prentice Hall, 663 p. 